\title{
Consensus
}

Volume 27

Issue 2 In Honour of the Women of the ELCIC

Article 17

$11-1-2001$

\section{Bonhoeffer: a theology of sociality}

Philip Gordon Ziegler

Follow this and additional works at: http://scholars.wlu.ca/consensus

Part of the Practical Theology Commons

\section{Recommended Citation}

Ziegler, Philip Gordon (2001) "Bonhoeffer: a theology of sociality," Consensus: Vol. 27 : Iss. 2 , Article 17. Available at: http://scholars.wlu.ca/consensus/vol27/iss2/17

This Book Reviews is brought to you for free and open access by Scholars Commons @ Laurier. It has been accepted for inclusion in Consensus by an authorized editor of Scholars Commons @ Laurier. For more information, please contact scholarscommons@wlu.ca. 
at times offensive by our standards, reflects a larger pastoral concern of a priest who was legitimately afraid of losing his parishioners to the large and established Jewish community of Antioch. Mayer and Allen are not uncritical of Chrysostom, but do place him firmly in his historical and pastoral context, with a solid and succinct overview of his rhetorical method within the conventions of ancient oratory. Of course, the book could say much more, but within the limits of a relatively short volume, Mayer and Allen produce a very workable and useful summary of the Golden-mouth's life and legacy.

A pastor, preacher, or interested student of early church history will find this handsome and engaging book to open up the world of two ancient and influential churches, Antioch and Constantinople, through the life, homilies, and writings of one of their more memorable pastors. I highly recommend John Chrysostom as a good investment for one's personal or church library.
Andrei S.P. Brennan
McMaster University
Hamilton, Ontario

\section{Bonhoeffer: A Theology of Sociality}

Clifford J. Green

Grand Rapids, MI: Eerdmans, 1999

392 pages, \$31.95 Softcover

This volume makes available to a new generation of students of the theology of Dietrich Bonhoeffer a landmark work of English language scholarship long out of print in its original 1975 edition. Green's work continues to represent one of the few enduring efforts in English to consider the developments and continuities of the whole of Bonhoeffer's corpus of writings.

The revisions to the new edition are significant. The scholarly apparatus of the work has been updated, reference now being made to the critical edition of the Dietrich Bonhoeffer Werke and parallel English translations where available. Eberhard Bethge's biography is also now cited in its recently republished and unabridged English edition. These revisions, in and of themselves, are invaluable. An index, absent from the earlier edition, is now also helpfully included. 
As to content, there are several notable revisions. First, is the welcome excision from the opening chapter of Green's survey and discussion of now-dated interpretations of Bonhoeffer from the 1960s. Second, is the addition of a chapter treating the Ethik, the absence of which was an oddity in the first edition. Third, is the inclusion as an appendix of some fifteen letters related to Bonhoeffer drawn from the papers of the late Paul L. Lehmann, including four letters, previously unknown, written to Lehmann by Bonhoeffer himself in 1932 and 1941. The correspondence is greatly interesting, but is most certainly an appendix to Green's work, having little relation to the argument he presses or, indeed, even to the theme of sociality he traces in Bonhoeffer's theology. In due time, these letters will be also appear in the appropriate volumes of the English Works.

The themes Green develops in this volume have in many ways become part of our present day common sense in relation to Bonhoeffer's achievement. Bonhoeffer's early theological works the dissertation, Communio Sanctorum and the Habilitationschrift, Act and Being - it is urged, inaugurate an effort to recast the key categories of Christian theology in terms of sociality. Ecclesiology, but also subsequently Christology, come to be comprehended with reference to sociality, i.e., in terms of an social ontology of persons and relations, indeed of persons in relation. Bonhoeffer's evangelical clarification of God's freedom as "freedom-for-us," the consideration of the presence of Christ as "Christ existing in and as community," the shift of the christological question from the epistemological "how?" of the God-man to the personal "who?" of the Incarnate One, the development of soteriological ideas of Kollektivperson and Stellvertretung, and the treatment of sin as default on proper creaturely relations and reciprocal limitations - all of these, Green persuasively argues, evidence Bonhoeffer's ongoing effort to make manifest the "social intention of all basic Christian concepts." It is thus Green's contention that attending to Bonhoeffer's theological anthropology is as important to a proper grasp of his overall achievement as is consideration of his Christology. In fact, despite notable shifts in emphasis, the Christology, with its uncompromising ecclesiological setting, represents an effort at what the later Barth called "theanthropology," i.e., a theological anthropology in which God and the human are thought only in terms of the reality of the reconciled 
relation that obtains between them in Jesus Christ. This has important soteriological consequences, the chief of which, Green argues, is to make the problem of dominating power - its destructive application and its salutary differentiation from creaturely capacity - central to Bonhoeffer's account of salvation in a way that sets him at some distance from traditional Lutheran emphases. In each chapter, Green extends his thesis to subsequent stages in Bonhoeffer's work, demonstrating how the "theology of sociality" formulated in the early work continues to provide the decisive basis for later developments, thereby illuminating a significant degree of continuity across works often thought to be quite divergent, e.g., Discipleship and the Letters \& Papers.

Throughout, Green also contends for the importance of what he calls the "autobiographical dimension" of Bonhoeffer's theology, i.e., the manner in which certain key themes and emphases in the theology reflect the circumstances of Bonhoeffer's life. This is one of the interesting aspects of the newly added chapter on the Ethik. Green's interpretation of these manuscripts lays particular stress not only on the evident impress of the theology of sociality - seen, e.g., in the centrality of vicarious representative action and the characterization of mutually delimiting "mandates" on the model of collective persons but also on the text's justification of active political resistance and tyrannicide, and the many not so veiled references to the immediate context of Nazi governance in the text.

Philip G. Ziegler

Princeton University

\section{Martin Luther's Theology: Its Historical and Systematic Development}

Bernhard Lohse, Translated and Edited by Roy A. Harrisville Minneapolis, MN: Fortress Press, 1999

393 Pages, \$66.00 Hardcover

Pastors and academics with an interest in Luther will want to keep this book within arm's reach. Bernhard Lohse has produced a masterful study which attends to the wide sweeping scope of Luther's theology as well as the intricate details at the necessary points. The subtitle of the 